JOAL, (JOURNAL, OF APPIIII) LINGUISTIICS ANI) LITIRA'TURE)

Vol. 5 No. 1,2020

ISSN (print): 2502-7816; ISSN (online): 2503-524X

Available online at https:/ / journal.unib.ac.id/index.php/joall/index doi: http://dx.doi.org/10.33369/joall.v5i1.10046

\title{
CONFIDENCE: BEFORE AND AFTER ORAL RECITATIONS
}

\author{
Jerald C. Moneva ${ }^{1}$; Audrey Jane P. Cuizon² \\ Jagobiao National High School, Philippines ${ }^{1,2}$ \\ Corresponding email: freezingfire1979@gmail.com
}

\begin{abstract}
A belief in one's capability to do and perform the task well is referred to as self-confidence. Meanwhile, oral recitation is a form of speaking in front of other people to report information. Hence, this study was conducted in Jagobiao National High School- Senior High School Department. The researcher-made likert scale questionnaire was used to assess the students from the different strands, aimed to know the students' confidence regarding their oral recitation performance and students' confidence before and after they perform oral recitations. Moreover, the quantitative data were analyzed through weighted mean and paired samples t-test. In which, the result shows improvement of students' confidence after ten or more times of performing oral recitations due to their intensive oral participation. It means that when a student is highly confident then she or he is able to perform the oral participation efficiently. Thus, it revealed that there is a significant difference between students' confidence before and after oral recitations. In this study, suggestions were provided to students such as engaging in different activities that could enhance their confidence in all aspect and to the teachers and parents who need to help the students to perform well in school with self-confidence.
\end{abstract}

Keywords: Oral recitation, Self-confidence, Senior High, Students

\section{INTRODUCTION}

Self-confidence is a trust in one's self, abilities, and skills in order to do the tasks and achieve goals. There are lots of factors that influence the speaking activities and one of those is the affective factor in which it relates to the emotional aspect of an individual. It came from the word "affect" which means emotion. Minghe \& Yuan (2013) state that there are two related aspects of affective factor and those are relational factors and individual 
factors of learners wherein it includes motivation, anxiety, and selfconfidence. Among all of these, self-confidence is the most influential factor in the progress of one's speaking skills.

In order to have an effective communication, they must develop their communication skills. One of the most effective ways to increase the student's communication skills is oral recitation. In which, oral recitation is an act of saying something aloud in public. It is also an act of student's reply to a question.

In Jagobiao National High School, the student's performance on their oral recitation is poor. It is because some students felt uneasy and anxious when they are asked to do oral recitations. They are afraid to speak in front of the class. Their communication skills are not yet fully developed because they cannot communicate very well. They tend to have low self-confidence. But since the teachers keep on giving a task and have it performed orally in front of the class, their self-confidence is boosting and increasing.

For every individual, it is very important to be confident as it can help interact and communicate with other people without hesitations. Being confident can seize moments and opportunities especially in a scholarly works and performances. On one hand, having too little confidence can be a hindrance of an individual from taking such opportunities in school, social life and beyond. Students should develop their self-confidence through experiencing different activities and having a positive mindset.

Based on the results of Salim (2015) through documentation and questionnaire, there is a positive correlation between the self-confidence and the students' performance in the oral presentation as both variables influence each other. Wherein, the students who have high self-confidence can communicate well and is able to conquer anxiety and negativity. Meanwhile, students who have low self-confidence have a difficulty to speak in front of the class. Al-Hebaish (2012) finds out that the general sellconfidence affects the quality of oral performance in which the level of general self-confidence is a significant factor of a student's academic achievement. According to Jarvis (2014) there is a significant effect of selfconfidence in oral performance.

Thus, the main objective of the study is to know the students' confidence before and after ten or more times of performing oral recitations and to know if there is a significant difference between students' confidence before and after oral recitations of all senior high school students in Jagobiao National High School.

\section{METHODS}

The data was collected from the population of all senior high school students of Jagobiao National High School. The grade 11 has five strands which are 
Accounting and Business Management (ABM) with 27 students, Humanities and Social Sciences (HUMSS) with 43 students, Science Technology Engineering and Mathematics (STEM) with 35 students, General Academic Strand (GAS) with 40 students, and Technical Vocational (TECH-VOC) with only 8 boys. For the grade 12, there are only three strands and that includes ABM with 29 students, HUMSS with 45 students and GAS with 23 students. Overall, there are 250 respondents.

\section{Instruments}

A researcher-made likert scale questionnaire was used to find out the student's confidence before and after ten or more items of oral recitations. The questionnaire has 10 statements referring to their confidence before and after oral recitations. The statements were rated through the five options which are extremely (5), very (4), moderately (3), slightly (2), and not at all (1).

\section{Data Analysis Procedures}

The data acquired was analyzed through weighted mean and paired samples t-test through SPSS to find out if the level of students' confidence has significant difference between the before and after oral recitations.

\section{FINDINGS}

Table 1. Students' Confidence Before Oral Recitations

\begin{tabular}{|c|c|c|}
\hline Indicators & $\begin{array}{l}\text { Weighted } \\
\text { Mean }\end{array}$ & Interpretation \\
\hline $\begin{array}{l}\text { 1. I am not shy to perform oral recitation in front } \\
\text { of the class }\end{array}$ & 2.76 & Moderately \\
\hline 2. I can speak very well in front of the class & 2.44 & Slightly \\
\hline 3. I can do oral recitations with just few mistakes & 2.46 & Slightly \\
\hline $\begin{array}{l}\text { 4. I am very comfortable speaking in front of the } \\
\text { class }\end{array}$ & 2.37 & Slightly \\
\hline $\begin{array}{l}\text { 5. I am able to do oral recitations better than my } \\
\text { classmates }\end{array}$ & 2.16 & Slightly \\
\hline $\begin{array}{l}\text { 6. I believe I can answer the follow-up questions } \\
\text { given. }\end{array}$ & 2.46 & Slightly \\
\hline $\begin{array}{l}\text { 7. I believe I can get an excellent performance on } \\
\text { oral recitations }\end{array}$ & 2.48 & Slightly \\
\hline $\begin{array}{l}\text { 8. I am not afraid to raise my hand every time } \\
\text { there is an oral recitation }\end{array}$ & 2.49 & Slightly \\
\hline $\begin{array}{l}\text { 9. I maintain good posture when I am doing oral } \\
\text { recitations }\end{array}$ & 2.56 & Slightly \\
\hline $\begin{array}{l}\text { 10. I am not trembling every time I do oral } \\
\text { recitations }\end{array}$ & 2.35 & Slightly \\
\hline Overall weighted mean & 2.45 & Slightly \\
\hline
\end{tabular}


LEGEND: 1.00-1.80 (Not at all); 1.81-2.60 (Slightly); 2.61-3.40 (Moderately); 3.41-4.20 (Very); 4.21-5.00 (Extremely)

The table above reveals that students were slightly confident before oral recitations with overall weighted mean which is 2.45 . In terms of the indicators, the statement 1 which is "I am not shy to perform oral recitation in front of the class" was interpreted as moderately with weighted mean 2.76. It indicates that students have average feeling of shyness when they perform oral recitation in front of the class. Cabe \& Selatan's (2012) study results showed that being shy is part of a person's personality. The statement 9 which has 2.56 weighted mean, shows that students' doesn't really maintain good posture when they are doing oral recitations. The statement 8 "I am not afraid to raise my hand every time there is an oral recitation has weighted mean of 2.49 and was interpreted as slightly. It means that most students were afraid to raise their hands when there is an oral recitation.

Most probably, students were not really comfortable speaking in front of the class. They are trembling most of the time when they do oral recitations. This result is in line with Al-Hebaish's (2012) study which revealed that students who are not so confident were the ones who are uncomfortable and frightened. And lastly, with the lowest weighted mean of 2.16, it was shown that students were not so confident with their ability which it was stated that they are not able to do oral recitations better than their classmates do. Salim (2015) indicated that students who have low selfconfidence have hard times to speak in front of other people.

Table 2. Students' confidence before oral recitations

\begin{tabular}{|c|c|c|}
\hline \multirow{2}{*}{$\begin{array}{l}\text { Indicators } \\
1 \text { I I am not shy to perform oral recitation in front }\end{array}$} & \multicolumn{2}{|c|}{ Weighted MeanInterpretation } \\
\hline & & \\
\hline of the class & 3.17 & Moderately \\
\hline 2. I can speak very well in front of the class & 3.00 & Moderately \\
\hline 3. I can do oral recitations with just few mistakes & 2.96 & Moderately \\
\hline $\begin{array}{l}\text { 4. I am very comfortable speaking in front of the } \\
\text { class }\end{array}$ & 3.04 & Moderately \\
\hline $\begin{array}{l}\text { 5. I am able to do oral recitations better than my } \\
\text { classmates } \\
\text { 6. I believe I can answer the follow-up questions }\end{array}$ & 2.69 & Moderately \\
\hline $\begin{array}{l}\text { given. } \\
7 \text {. I believe I can get an excellent performance on }\end{array}$ & 3.02 & Moderately \\
\hline $\begin{array}{l}\text { oral recitations } \\
8 \text {. I am not afraid to raise my hand every time }\end{array}$ & 2.95 & Moderately \\
\hline
\end{tabular}


there is an oral recitation

9. I maintain good posture when I am doing oral recitations

10. I am not trembling every time I do oral

recitations

Overall weighted mean

LEGEND: $1.00-1.80$ (Not at all); 1.81-2.60 (Slightly); 2.61-3.40 (Moderately); 3.41-4.20 (Very); 4.21-5.00 (Extremely)

The table 2 shows improvement in which, after ten or more times of performing oral recitations, students are moderately confident with overall weighted mean of 2.99 compared to before oral recitations, students' confidence is just slightly high. At this point, students were moderately shy when they are to perform oral recitations, maintain good posture when doing oral recitations, and comfortable speaking in front of the class. This means that students' were more confident after ten or more times performing oral recitations than their first attempt. This result is supported by Martinez \& Villa (2017) result which showed that students are capable of speaking English after several times of exposure to a task. Meanwhile, the study of (Salim, 2015) revealed that students' with high self-confidence were more assured in speaking up than those low confident learners.

Table 3.Paired Samples t-test of students' confidence before and after oral recitation

\begin{tabular}{ccccc}
\hline & Mean & $\mathrm{N}$ & Std. Deviation & $\begin{array}{c}\text { Std. Error } \\
\text { Mean }\end{array}$ \\
\hline BEFORE ORAL & 24.518 & 245 & 7.481 & .478 \\
\hline AFTER ORAL & 29.890 & 245 & 7.580 & .484 \\
\hline
\end{tabular}

The table 3 reveals the mean score of students' confidence after ten or more times oral recitation (29.890) is much higher than students' confidence before performing oral recitations which has only 24.518 mean score. It also shows that their standard deviation was about the same. 
Table 4. Differences of students' level of confidence before and after oral recitations

\begin{tabular}{|c|c|c|c|c|c|c|c|c|}
\hline & \multicolumn{5}{|c|}{ Paired Differences } & \multirow{3}{*}{ 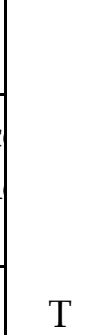 } & \multirow[b]{3}{*}{ Df } & \multirow{3}{*}{$\begin{array}{l}\text { Sig. } \\
(2-\text { tai } \\
\text { led })\end{array}$} \\
\hline & \multirow[b]{2}{*}{ Mean } & \multirow{2}{*}{$\begin{array}{l}\text { Std. } \\
\text { Deviatio } \\
\mathrm{n}\end{array}$} & \multirow{2}{*}{$\begin{array}{l}\text { Std. } \\
\text { Error } \\
\text { Mean }\end{array}$} & \multicolumn{2}{|c|}{$\begin{array}{ll}95 \% & \text { Confidend } \\
\text { Interval of th } \\
\text { Difference }\end{array}$} & & & \\
\hline & & & & Lower & Upper & & & \\
\hline $\begin{array}{l}\text { BEFOREORA } \\
\text { L - } \\
\text { AFTERORAL }\end{array}$ & -5.371 & 7.306 & .467 & -6.291 & -4.452 & $\begin{array}{c}-11.50 \\
7\end{array}$ & 244 & .000 \\
\hline
\end{tabular}

The paired samples t-test statistics was used to analyze the students' confidence before and after oral recitations. This revealed that the sig. (2tailed) value is .000 in which is lesser than the alpha (0.05). The decision is reject Ha. Hence, there is a significant difference between students' confidence before and after they perform oral recitations. In which, it means that self-confidence is one of the factors which greatly affect the performance of students on oral recitations. This finding is supported by (Gürler, 2015) study in which he stated that there is a significant relationship between the students' self-confidence and accomplishment on speaking.

Fook et al. (2011) revealed that students prefer to perform oral presentation in a teacher-student setting because it gave them less feeling of nervousness than presenting individually in front of other people. Meanwhile, RI (2015) stated that students find hardships in stating their thoughts and ideas in front of other people. Juhana (2012) stated that students' are afraid to commit mistakes and afraid to be laughed at and judged by another person that is why they can't perform oral recitations well.

\section{DISCUSSION}

The study revealed that the level of students' self-confidence before the oral recitation is slightly high because they believe that they can't perform oral recitations due to low self-confidence. 
Meanwhile, the level of students' self-confidence after the oral recitation is moderately high because they are more confident in performing in front of their classmates and they have the belief and confidence that they can speak in front of the class well.

It was presented that the level of self-confidence of the students before and after oral recitations has a significant difference. This means that there is an improvement on students' oral performance after the oral recitation.

\section{CONCLUSION AND SUGGESTIONS}

In this study, it implies there is a significant difference between the students' confidence before and after ten or more times they do oral recitations. Thus, students have much confidence when they are engage more on oral recitations. Wherein, learners became more confident to speak in front of the class and do oral recitation after an intensive oral participation in the classroom. Students have improvements in their oral presentation ability when they are more confident. Meanwhile, students who have low selfconfidence tend to have low academic achievement in their oral recitation. This means that confidence influences the students' performance on oral recitations. Therefore, Students should engage different activities that will help to boost their self-confidence.

Teachers should create effective and enjoyable teaching strategies in order to enhance the students' self-confidence. Parents should monitor their children's weaknesses when it comes to oral recitation and try to find the best way to improve it.

\section{REFERENCES}

Al-Hebaish, S. M. (2012). The correlation between general self-confidence and academic achievement in the oral presentation course. Theory and Practice in Language Studies, 2(1), 60-65. https:/ / doi.org/10.4304/tpls.2.1.60-65

Cabe, P., \& Selatan, T. (2012). Psychological Factors That Hinder Students from Speaking in English Class ( A Case Study in a Senior High School in South. Journal of Education and Practice, 3(12), 100-110.

Fook, C. Y., Sidhu, G. K., Rani, N., \& Aziz, N. A. (2011). Analyzing factors associated with students' oral test performance. The International Journal of Educational and Psychological Assessment, 9(1), 27-47.

http:/ / search.ebscohost.com/login.aspx?direct=true\&db=psyh\&AN=2 012-28408-003\&site=ehost-live

Gürler, İ. (2015). İngilizce Öğretmenliği ve İngiliz Dili ve Edebiyatı Hazırlık Öğrencilerinin Özgüven ve Konuşma Becerileri Arasındaki İlişki. Curr Res Soc Sci Curr Res Soc Sci Curr Res Soc Sci, 1(12), 14-19. 
Jarvis, P. (2014). From adult education to lifelong learning and beyond. Comparative Education, 50(1), 45-57. https:// doi.org/10.1080/03050068.2013.871832

Martinez, E. A., \& Villa, O. E. S. (2017). A quantitative study of self confidence in learning English as a foreign language. Academia Journal of Educational Research, 5(2), 24-28. https://doi.org/10.15413/ajer.2017.0302

Minghe, G., \& Yuan, W. (2013). Affective Factors in oral English Teaching and Learning. Higher Education of Social Science, 5(3), 57-61. https://doi.org/10.3968/j.hess.1927024020130503.2956

RI, K. (2015). No Title空間像再生型立体映像の 研究動向. Nhk技研, 151(1), 10-17. https:// doi.org/10.1145/3132847.3132886

Salim, A. (2015). General Self-Confidence and Its Implication on Students' Achievement in Oral Presentation. JEELS (Journal of English Education and Linguistics Studies), 2(2), 34-48.

https://doi.org/10.30762/jeels.v2i2.95 